\title{
Sensitivity analysis of the use of Life Cycle Impact Assessment methods: a case study on building materials
}

Bueno, Cristiane; Hauschild, Michael Zwicky; Rossignolo, Joao Adriano; Ometto, Aldo Roberto; Crespo Mendes, Natalia

Published in:

Journal of Cleaner Production

Link to article, DOI:

10.1016/j.jclepro.2015.10.006

Publication date:

2016

Document Version

Peer reviewed version

Link back to DTU Orbit

Citation (APA):

Bueno, C., Hauschild, M. Z., Rossignolo, J. A., Ometto, A. R., \& Crespo Mendes, N. (2016). Sensitivity analysis of the use of Life Cycle Impact Assessment methods: a case study on building materials. Journal of Cleaner Production, 112, 2208-2220. https://doi.org/10.1016/j.jclepro.2015.10.006

\section{General rights}

Copyright and moral rights for the publications made accessible in the public portal are retained by the authors and/or other copyright owners and it is a condition of accessing publications that users recognise and abide by the legal requirements associated with these rights.

- Users may download and print one copy of any publication from the public portal for the purpose of private study or research.

- You may not further distribute the material or use it for any profit-making activity or commercial gain

- You may freely distribute the URL identifying the publication in the public portal 
Bueno, C.; Hauschild, M.Z.; Rossignolo, J.A.; Ometto, A.R ; Mendes, N.C. (2016) Sensitivity analysis of the use of Life Cycle Impact Assessment methods: A case study on building materials. Journal of Cleaner Production Volume: 112 Pages: 2208-2220. DOI: 10.1016/j.jclepro.2015.10.006

\section{Sensitivity Analysis of the use of Life Cycle Impact Assessment \\ Methods: A case study on building materials}

\section{Cristiane Bueno (corresponding author)}

Postdoc researcher at the Architecture and Urbanism Institute, University of São Paulo, e-mail: cbueno@sc.usp.br.

Postal Adress: Alameda das Tulipas, 150, Dourado - SP, Brazil. Postal Code: 13590-000.

Telephone number: +55 $1633453898 /+551681286432$

\section{Michael Zwicky Hauschild}

Associate Professor, Department of Management Engineering, Technical University of Denmark, e-mail: $\underline{\text { mzha@dtu.dk }}$

\section{João Adriano Rossignolo}

Associate Professor, Faculty of Animal Science and Food Engineering, University of São Paulo, email: rossignolo@usp.br

\section{Aldo Roberto Ometto}

Associate Professor, Sao Carlos Engineering School, University of São Paulo, e-mail: aometto@sc.usp.br

\section{Natália Crespo Mendes}

$\mathrm{PhD}$ at Department of Management Engineering, Technical University of Denmark, e-mail: cm.natalia@gmail.com

\footnotetext{
ABSTRACT

The main aim of this research is to perform a sensitivity analysis of a Life Cycle Assessment (LCA) case study to understand if the use of different Life Cycle Impact Assessment (LCIA) methods may lead to different conclusions by decision makers and stakeholders. A complete LCA was applied to non-load-bearing external climate walls for comparative purposes. The LCIA phase of the case study was performed using five different Impact Assessment Methods: EDIP 97/2003 (midpoint), CML 2001 (midpoint), Impact 2002+ (endpoint and midpoint), ReCiPe (endpoint and midpoint) and the ILCD recommended practices for LCIA (midpoint). The endpoint results were compared aggregately, and the midpoint categories concerning similar potential impacts were compared individually for the analysis of possible deviations. The observations and comparisons involved
} 
mostly the decision maker's point of view and not the differences among the characterization models. The endpoint LCIA showed that the only two methods which applied such an approach (Impact 2002+ and ReCiPe) provided different results and led to different conclusions. For midpoint LCIA, the results were completely consistent for the following impact categories: General Eutrophication, Aquatic and Freshwater Ecotoxicity, Ionizing Radiation, Particulate Matter Formation, and Resources Depletion. Global Warming, Terrestrial Ecotoxicity, Human Toxicity (except for the Non-carcinogens impact category) and Land Use (except for Natural Land Transformation) showed partially consistent results and pointed out to the same worst environmental alternative, but with a slightly different impact profile among the other alternatives. Ozone Layer depletion and Photochemical Oxidant Formation categories showed discrepant results and the impact profile differences between the older and newer methods were notable. Acidification, Terrestrial and Aquatic Eutrophication, Marine Ecotoxicity and Water Depletion showed substantially inconsistent results.

Keywords: Life Cycle Assessment; Life Cycle Impact Assessment; LCIA methods; Sensitivity Analysis.

\section{INTRODUCTION}

Over 50 Life Cycle Impact Assessment (LCIA) models are currently available in Europe [1]. They are specific techniques related to environmental impacts that comprise the scope of evaluations in that region and have been implemented within various of the most broadly applied LCIA models, such as Eco Indicator 99 [2], EDIP 97 [3], EDIP 2003 [4], (Dutch) Handbook on Life Cycle Assessment (LCA) (CML2002) [5], EPS 2000 [6], Impact 2002(+) [7], Swiss Ecoscarcity (Ecopoints 2006) [8], TRACI [9], ReCiPe [10], MEEuP [11] and LIME [12]. Recently a recommendation of the best practices on LCIA according to the ILCD has been published, and the beta version of the new Impact World + method is under testing.

Most of these methods have been developed within the European regional scope. However, efforts have been devoted to expanding the scope of their application considering the regional spatial differences of world environments.

The main features of the existing LCIA methods can be classified according to several parameters. The methods can be grouped by the level of evaluation at midpoint or endpoint, and some methodologies have a combined approach, comprising sets of characterization factors (CF) at midpoint and endpoint.

The evaluation methodologies of CML 2001, EDIP 97-2003, MEEuP and TRACI are purely at the midpoint level. 
Methods Eco-indicator 99 and EPS 2000 strictly have an endpoint assessment approach. A third group consists of combined methodologies, with sets of impact categories at midpoint and endpoint. This group comprises the Impact 2002, Swiss Ecoscarcity 06, ReCiPe 2008 and Impact World + methods.

The ILCD recommended practices are still available only for midpoint impact categories. An important nuance observed in such methodologies refers to the geographical scope of the impact categories, also called regional validity by the ILCD Handbook [13]. Some methodologies are directed to specific regional contexts, therefore all impact categories are applicable regionally/locally, except those which are global by definition, as global warming, ozone layer depletion and consumption of resources. Some of these methodologies consider even the consumption of non-renewable resources as a category of local coverage, as, for instance, LIME, directed exclusively to the Japanese context, TRACl, which was developed by the United States Environmental Protection Agency, built on the environmental characteristics of North America, and Swiss Ecoscarcity, developed for the Swiss scenario. The new Impact World+ methodology was developed to be applied in a global scope. Most of the categories of the other methods are directed to the European environment.

There is no consensus on normalization and weighting methods among the methodologies, and most of them have developed their own approaches.

Finally, regarding the impact categories addressed, the subject of a category in a given methodology is directly related to its level of assessment (midpoint or endpoint) and context of creation, because the issues addressed reflect, in most cases, the areas of higher sensitivity to the environmental context of the methodology. The categories related to climate change (or global warming) and ozone layer depletion, as well as issues related to resource consumption and waste generation are present in almost all midpoint methodologies.

Therefore the characteristics of such LCIA methodologies vary considerably and interfer with the final results of the LCIA.

Many LCIA methods have been developed and applied to LCA studies, however none have been internationally accepted according to the requirements of ISO. There is no guideline that helps the LCA practitioner choose between characterization models and factors, and the results of some impact categories are very different [14].

To check whether the LCA results and conclusions vary according to the method used, some studies have been designed to compare LCIA methods. Dreyer, Niemann and Hauschild [15] used EDIP 97, CML 2001 and Ecoindicator 99 to evaluate six impact categories and perform a quantitative comparison regarding the characterization and normalization indicators and a qualitative comparison on the weighting. They found out that for EDIP97 and CML2001 the 
chemical impacts on human health and ecosystem health showed the most significant discrepancies, and for EDIP97 and Eco-indicator 99 the patterns of most important contributors are rather different and the results of the two methods may lead to different conclusions. Pant et al [16] has compared three different LCIA methods for aquatic ecotoxicity (EDIP 97, CML 2001 and Impact 2002+) and identified significant differences between the LCIA methods in terms of data needs and results. The authors concluded that part of deviating results are due to differences in the fate and exposure modelling and in the toxicological effect calculations, however, the main reason remains in the calculation of the residence time of emissions in the water compartments.

Rosenbaum et al. [17] aimed to provide science-based guidance for health effects modelling in comparative assessments based on human exposure and toxicity, and concluded that the latest studies tend to consider a larger number of methods and apply those most recently developed (as USEtox in the specific case of such impact categories).

The comparisons of the impacts on human health made by Caneghem, Block and Vandecasteele [18] included the CFs provided by the CML, Eco-indicator 99, EPS, EDIP and USEtox, and indicated that those can influence conclusions on the trend of the effects over time and the relative contribution of the individual substances.

Pizzol et al [19] [20] compared nine different LCIA methods used in the assessment of impacts of metals on human health and eight different methods for aquatic and terrestrial ecosystems impact assessment. For both studies, in general, the analizes showed poor or no agreement among the methods, once the contribution of each metal to the total impact changes largely according to the LCIA method chosen. For impacts on human health such differences mainly regarded the number of metals included in each method and the calculation method used within the characterization factors. For impacts on the aquatic and terrestrial ecosystems the characterization phase also showed to be critical in determining the differences among methods, however, most of the methods showd a tendency to associate the largest share of the total eco-toxicological impacts to metals.

Cavalett et al. [21] used a biofuels case study to compare seven methods and obtained similar results for global impacts and difficulties for comparison in other categories due to the use of different indicators.

Most studies showed divergent values between different methods due to the different $\mathrm{CF}$ and models adopted. Hauschild et al [14] compared the characterization models for each impact category present in the most applied methods and recommended the best practices on LCIA. Despite the significant number of comparative studies carried out, it is relevant to perform an updated comparison study including the methods recently developed and that have not been 
considered in previous comparisons, as ReCiPe and the ILCD recommended practices. Potential discrepancies in the LCIA results from different methods have a fundamental importance for the LCA practitioner once they may provide misleading results. Moreover, most of the previously performed studies focused mainly in the Human Toxicity and Ecotoxicity categories and have not considered all other categories involved in a LCIA, and which are also very significant in terms of discrepancies in the results.

Thus the main unprecedented contribution of this research is the comparison of the results of most of the impact categories from the oldest cutting edge methods and the newest ones currently applied, pointing out the main leverage points and possibilities of masking and manipulating results by selecting the more convenient methodologies and characterization factors.

In the present research the possible implications and consequences of the chosen method on the final results of a case study are analyzed for the understanding of the implied limitations due to the choice during the scope definition. This discussion will be conducted through a sensitivity analysis of an LCA case study on the use of different LCIA methods.

\section{METHODS}

A complete LCA study was applied for comparative purposes, to be disclosed to the public. The methodology was guided by ISO 14044 [22] through the application of the script proposed by ILCD Handbook [13].

The case study was performed by using GaBi 4.4 [23] software and data from Ecoinvent 2.01 database [24]. The results of all alternatives were compared so that an overview of the potential environmental impacts from each alternative could be obtained.

Five different methods were applied for the LCIA phase: three former methodologies - EDIP 97/2003 [3] [4], CML 2001 [5] and Impact + 2002 [7] - and more recently developed methodologies - ReCiPe 2008 [10] and ILCD recommended practices [14]. The choice of the methods was based on the most broadly applied on the European context. The LCIA was performed at the midpoint for all methodologies and at the endpoint for the Impact + 2002 and ReCiPe 2008 methodologies, since only these methods have an endpoint approach. The mid-point and end-point methodologies were treated separately in the comparison.

The comparison of the methods was based on the decision-makers' point of view and did not go deeper in the CF scientific background. However variances in the CF were identified to explain discrepancies in the results.

The comparison of the mid-point results was focused on the impact categories covered by all five mid-point methodologies. The impact categories discussed in this paper were global warming, 
ozone depletion, photochemical oxidation, acidification, eutrophication, ecotoxicity and human toxicity.

The Resources Depletion category was not deeply analyzed as it has different approaches among LCIA methods which can be stricter - as metal and fossil depletion in ReCiPe methodology - or more comprehensive - as Abiotic Depletion in CML and ILCD methods. Such categories were considered "non comparable" due to their different conceptual approaches and were briefly discussed in the results.

The only Resources-related category deeply analyzed was Water Depletion to understand whether the diverse assessment methods adopted by ReCiPe and ILCD methodologies might lead to different results.

The methods agree on characterization models, indicators and units only for global warming and ozone depletion. The indicator results were harmonized at the level of characterization and the results were analyzed under both scientific and decision-maker points of view. Such a harmonization involved only a direct conversion of different indicators into common metrics, however no underlying model was harmonized for the retention of its characteristics.

\subsection{CASE STUDY}

The five methodologies were applied to a comparative Life Cycle Assessment (LCA) of three different non-structural external wall systems. The aim was to compare the environmental impacts of the solutions from a life cycle perspective to point out the most environmentally friendly solution. Buildings with independent structures were considered and the external walls analyzed had only a sealing function.

The functional unit addressed in this research was $1 \mathrm{~m}^{2}$ of a non-structural external climate shell/wall which provides thermal and acoustic performance as required by relevant Brazilian standards for the application in the bio-climatic zone 3 [25], related to the city of Sao Paulo, for a period of 40 years (minimum durability fixed by NBR 15575-1 [26] for external wall systems. The following alternatives were compared:

a) $14 \mathrm{~cm}$ thick masonry of clay blocks;

b) $14 \mathrm{~cm}$ thick masonry of concrete blocks;

c) $12 \mathrm{~cm}$ thick lightweight concrete panels;

d) $15 \mathrm{~cm}$ steel framing walls system with internal and external $4 \mathrm{~cm}$ thick wood-filled fibercement boards and an $8 \mathrm{~cm}$ thick unventilated air chamber;

We aimed at a full equivalence of the alternatives, so that they could be compared without misleading results. This equivalence was based on thermal, acoustic and structural performance 
requirements established by NBR 15575-1 [26], NBR 15220 [25], NBR 10151 [27] and NBR 10152 [28] standards.

The product systems compared in this LCA study are shown in Figures 1, 2, 3 and 4. They were modeled in $\mathrm{GaBi}$ software (version 6) using Ecoinvent database version 2.01 and $\mathrm{GaBi}$ implementation of the five LCIA methodologies [23] [29].

As this LCA study was conducted for the prioritization of wall systems in a Brazilian context, the modeling of inventory data should be as close as possible to the Brazilian actual processes. As the Brazilian inventory data available is scarce, this study have used the energy grid mix and the recycling averages for aluminum and steel are in accordance with the Brazilian government reports [30] [31] [32] in order to get inventory numbers as similar as possible.

The use phase of the analyzed systems was not considered in this study, since the behavior of the five wall alternatives can be assumed identical in terms of durability and maintenance, implying equal impacts during the service life of the walls, as shown in the table A1 in the appendix section. It's also important to highlight at this point that no insulation material was applied to fill in the walls, due the Brazilian climate requirements, as well as construction traditional practices and typologies in such country.

The inventories of the most important flows for the wall systems (Tables A2, A3, A4 and A5) as well as more detailed information on the scope of the performed case study are shown in the paper appendix.

For the categories in which a contribution analysis was required, the results were shown only for the masonry of clay blocks wall. This typology was chosen as it is one of the most traditional construction systems in Europe and Brazil.

As a guidance to understand the intrinsic differences among LCIA methodologies and the path applied to make them comparable, Table 1 shows the indicator units for impact categories among the investigated mid-point methodologies and Table 2 provides the conversion factor for the metrics harmonization.

\section{RESULTS AND DISCUSSION}

Table 3 shows results for the sensitivity analysis of the wall comparison to the use of different LCIA methods, considering always the worst environmental result from ReCiPe method as the reference value $(1,000)$. The absolute LCIA midpoint results can be found in the paper appendix.

The first important point to be highlighted is that it is necessary to discuss the uncertainties of the results. If they are large in a given case study, differences in the ranking are not so meaningful for discussion since they reflect differences in uncertainties. 
The results showed consistent for the Global Warming category (also called Climate Change in some methodologies). Despite the differences in the impact magnitude, all the methodologies showed almost the same gradation from the best to the worst environmentally friendly alternative. In this case, a decision-maker would draw the same general conclusions independently of the LCIA method applied. However there is a slight difference in the results of the older and newer methods regarding the steel framing system with internal and external fiber cement panels. Among the four alternatives analyzed this pattern is mostly the same across all LCIA methods. The impact of the Masonry of concrete blocks is always lower in comparison to the Lightweight concrete walls, once the amount of concrete and Portland cement used is also considerably smaller. The impacts of the concrete blocks masonry are fairly low in comparison to the masonry of clay blocks due to the large quantity of energy necessary for the block burning process, which is performed at significantly high temperatures and with large amounts of natural gas. Finally the main reason for the steel framing systems to be more impacting than the concrete blocks is related to the steel production and galvanization process, which are also highly energy-demanding. The contribution analysis for this impact category (Figure 5) shows the same range regarding emissions of substances within each LCIA method. However, the older methods EDIP, CML and Impact 2002+ consider a negative impact regarding Carbon Dioxide sequestration for timber growth within the medium density wooden board production process, which is not considered by the newer characterization model used in ReCiPe and ILCD. This discrepancy between the old and new methods is visible only in the steel framing system because this is the only alternative that uses wooden products.

In the Ozone Depletion category the methods provided different results among the different methodologies. The masonry of clay blocks is the most impacting alternative in CML while lightweight concrete walls are most impacting in the EDIP 2003 methodology. The situation is similar when comparing Impact 2002+ and ReCiPe 2008 methodologies (which use the same indicator recommended as best practice by ILCD). The impact profile is similar for the three first alternatives, however the steel framing system walls were the most impacting alternatives in $\mathrm{ReCiPe}$, but not in Impact 2002+.

As the results for this category have very low values, only one substance missing a characterization factor in some of the methods may make a substantial difference. However as most ozone depleting substances emissions are probably not relevant anymore -their presence reflects the age of the underlying dataset -, this research is not going deeper in the analysis of such category.

The same type of variation occurs in the Photochemical Oxidation category. The three older methodologies (EDIP, CML and Impact 2002+) present different impact profiles. Although the most 
impacting alternative showed to be the same for these methods - the steel framing system with internal and external fiber cement panels - the ranking profile for the remaining alternatives is quite varied. The major variation occurs when the older methods are compared to ReCiPe 2008 (that uses the same indicator recommended as best practice by ILCD) which presented the masonry of clay blocks as the most impacting alternative. ReCiPe also provided a completely different impacting ranking for the remaining alternatives in comparison to the older methods, possibly leading to wrong conclusions.

On the other hand it is important to highlight that whether the EDIP 2003 method was considered instead EDIP 97, the results would be significantly similar to ReCiPe.

The contribution analysis (Figure 6) has shown emissions from completely different substances among the compared LCIA methods, which reflects the differences in the characterization factors applied and has led to such a variety of results. While the most contributing emissions for CML, EDIP and Impact 2002+ were unspecified NMVOC, Nitrogen Oxides were predominant in the contribution profile of ReCiPe and ILCD methods.

The results for Acidification were consistent in the impact profile for the different wall options. The lightweight concrete was the most impacting wall, even for the ILCD recommended practice, which uses a different indicator for the category.

The contribution analysis for Acidification (Figure 7) has shown consistent in relation to the contributing substances, with a high similarity between EDIP, CML and ReCiPe, and some differences in Impact 2002+.

Regarding the Eutrophication impact assessment, each method uses a different approach, i.e. some methods apply one single aggregated category and others divide such an impact assessment into terrestrial and aquatic eutrophication categories.

Only two methodologies have provided specific impact categories for Terrestrial Eutrophication: EDIP 2003 and ILCD recommended practices. Those methods use different units to measure the impact potential and the result is two totally different impact profiles, which do not present any consistency when compared.

Regarding Aquatic Eutrophication, the Impact 2002+ method applies an approach which considers all aquatic reserves in the same category. On the other hand, ReCiPe 2008 assesses Marine and Freshwater Eutrophication separately (for Marine Eutrophication it uses the same approach as ILCD method). The ranking is consistent among EDIP, Impact 2002+ and Freshwater Eutrophication in the ReCiPe methodology, showing the steel framing systems as the most impacting alternatives and following the same impact profile for the remaining wall typologies. However, for Marine Eutrophication in the ReCiPe methodology, the results are diverse and show 
the masonry of clay blocks as the most impacting alternative and a different impact ranking for the remaining wall options.

Finally, methodologies, as EDIP 97 and CML 2001 apply the Eutrophication assessment in an aggregated approach and provided consistent results between them. The Contribution Analysis for the Eutrophication category (Figure 8) has reinforced the conclusions discussed above. A further category with several subcategories is Ecotoxicity. The assessment of Ecotoxicity is divided into terrestrial, aquatic, freshwater and marine. For Ecotoxicity-related impact categories a large difference in the absolute magnitude of the results was found.

Concerning Terrestrial Ecotoxicity, only three methods provide characterization models. They have shown a similar impact ranking, however with strongly different magnitudes. The only discrepancy is observed in the impacts from the masonry of clay and concrete blocks, which have shown different results for each method. The contribution analysis (Figure 9) has shown completely different emission patterns among the methods, with different predominant substances: Formaldehyde in EDIP, Mercury and Chromium in CML, and Phosphorus emissions to soil in ReCiPe. Any similarity in the impact ranking was only a coincidence for this specific case study. The results for Freshwater Ecotoxicity were congruent for the $\mathrm{CML}$ and ReCiPe methods and have shown a different impact ranking only for EDIP methodology. However the same did not occur for Marine Ecotoxicity. For this impact category the most discrepant number was related to the impacts on the life cycle of lightweight concrete walls, which decreased from the most impacting alternative in the CML 2001 methodology to the third position in the ReCiPe method analysis. The congruency on the results of Aquatic Ecotoxicity for CML and ReCiPe may be only a coincidence of this specific case, once the main contributing substances showed to be different for the three methods analyzed (Figure 10). Ecotoxicity was applied as an aggregated impact category only by the ILCD recommended practices, therefore there was no other method with the same assessment approach for comparison.

A significant consistence was found in the Human Toxicity group of impact categories. The results of the three types of Human Toxicity found in EDIP 97 method were congruent with CML 2001, ReCiPe, ILCD recommended practices and the Carcinogens category from the Impact 2002+ method. After conversion into the same metric, the results provided a similar ranking for EDIP, $\mathrm{CML}$ and ReCiPe methodologies. However the contribution analysis (Figure 11) has shown that such consistency is only apparent, since the main contributing substances vary widely among methodologies. Each LCIA method evaluates such a category using a different approach, which leads most likely to inconsistent results among them. The lonizing Radiation and Particulate Matter Formation categories have shown consistent results for all the methods, independently of differences in the metrics, and led to the same conclusions in 
any method applied. For lonizing Radiation, the characterization methods applied in LCIA methodologies are very similar and have led to similar results.

Regarding Land Use impact assessment the impact profile varies among LCIA methods, although most of them have led to the same conclusion on the most impacting alternative: Steel framing system with internal and external fibercement panels. The only category/method which showed a different impact ranking was ReCiPe Natural Transformation, whose most impacting alternative was the lightweight concrete walls.

A larger diversity of results - and possible misleading conclusions - was found in the Resources Depletion impact assessment. This category comprised LCIA categories as Resources, Abiotic, Metal and Fossil Depletion and Non-renewable resources. Each category has a different model for accounting resources depletion by using more specific or aggregated approaches.

The Resources category of EDIP 97 method is a simple mass accounting of the resources (renewable and non-renewable) used by the product system. As it has no CF for resources depletion, it cannot be comparable to other methods.

Regarding Abiotic Depletion categories - applied in CML and ILCD recommended practices - the same characterization model is used, therefore, the same results were provided. Mineral Extraction (Impact 2002+) and Metal Depletion (ReCiPe) have also shown congruent results on impact profile and magnitude.

Finally, the Non-renewable energy (Impact 2002+) and Fossil Depletion (ReCiPe) impact categories also showed the same impact ranking for all wall alternatives, but with a different magnitude, due to the difference in the metrics.

Although the results seem to have some inconsistency, a deeper analysis has shown that they were perfectly consistent when all their specificities were considered.

The last impact category analyzed was Water Depletion. The only two methodologies which consider water depletion are the newer ones - ReCiPe and ILCD recommended practices - and although both apply the same units and metrics, the results were boldly different. While the ILCD recommended practices pointed out the steel framing system with internal and external fiber cement panels as the most impacting alternative, with a close impact magnitude among all the other wall options, the ReCiPe method showed the lightweight concrete wall as the most impacting alternative, with large magnitude differences among the five wall options. In this case, such discrepancy may not be attributed to the different metrics, but placed in the characterization model applied.

In summary, regarding midpoint LCIA, the ranking among the five alternatives compared has shown completely consistent in all methods for the following impact categories: General 
Eutrophication, Aquatic and Freshwater Ecotoxicity, lonizing Radiation, Particulate Matter Formation and Resources Depletion - this latter comparing only specific approached categories. Some categories, as Global Warming, Terrestrial Ecotoxicity, Human Toxicity (except for the Noncarcinogens impact category) and Land Use (except for Natural Land Transformation) have showed partially consistent results, pointing out to the same worst environmental alternative, but with some slightly different impact profile among the other alternatives. These results can be partially consistent in this specific case, however it might be considered a coincidence, since the differences in the ranking point to underlying inconsistence among the characterization models applied.

Other categories, as Ozone Layer depletion and Photochemical Oxidant Formation, have showed totally discrepant results. It is noteworthy that the impact profiles of the old methods were different from those of the newest ones.

Finally, a few categories as Acidification, Terrestrial and Aquatic Eutrophication, Marine Ecotoxicity and Water Depletion have shown substantially inconsistent results and established no pattern of change between the old and new methods.

\section{CONCLUSIONS}

Such results and considerations have impacted on the sensitivity in the choice of an LCIA method and led to the need for global recommendations of a best practice on such a choice during the scope definition.

This paper has focused mainly on characterization issues and the inclusion of normalization and weighting in further researches would introduce important sources of difference in the LCIA results. The central point of this discussion on the comparison of older and newer methods it to point out the possibilities of masking and manipulating results by selecting the more convenient methodologies and characterization factors. This statement was made clear through the results. For the most part of categories where the impact assessment results were coherent among methods, it showed to be only a coincidence once contribution analysis has shown completely different substances contributions profiles. It may means that it is possible for the user to get the better results by choosing a preferable impact assessment method which would make his product to seem environmentally better than other methods would do.

The variations among results from different methods are due to intrinsic differences on the characterization models which have different conversion factors for the same substance or even different contributing substances for same impact category. Such variations on the characterization models are mostly due to regional and temporal factors, and also to variations in research areas of the institutions where assessment methods are developed. 
Regional and temporal issues affect the characterization models, once a particular region may be more sensitive and susceptible to a potential impact than other, even a close one, as well as, over the years, in the same region, the concerned impacts of certain emissions can be mitigated, giving place to new concerns on different issues, due to dynamic market and production processes changes.

As such, the most appropriate methodology for an LCA study would always be the latest version, developed in the most similar context as possible to the studied scenario. However, despite the recent developments in this area, there are still insufficient methodological tools for impact characterization modelling for most regions in the world.

In this context, the main conclusion of such discussion is the need for the requirement of the use of more than only one method as a best practice during the LCIA phase in order to make the decisions based on a comparative LCA study better-grounded and reliable. Moreover, it point out to the need of the development of an unified global impact assessment method as a means to harmonized the consistency of results from different studies.

As the newest initiative, Impact World + method might be the one that is closest to reach such goal. This method has evaluation modules aimed to regional contexts, such as Latin America, North America, Europe, Asia, Africa and Oceania, in which specific regional data can be inserted, in order to make the impact assessment as targeted as possible. Therefore, the development of unified characterization models based on the regional environmental characteristics and applied on a common assessment structure already developed by the Impact World + , would result in more specific and standardized LCIA studies. This would increase the reliability of the LCA results, significantly reducing their inherent uncertainties.

This research focused strictly on the sensitivity of LCA results to the use of different LCIA methods. However, others decisions on the study scope would also interfere in the results and conclusions of an LCA. For instance, the database choice would also be a sensitive point of any LCA study. This research was developed with data from Ecoinvent 2.01, which was currently used at the time the case study was developed. After the update of such database to the version 3 , changes were made which would possible lead to different results. However, in this paper, efforts were concentrated on the sensitivity analysis of LCIA phase.

\section{ACKNOWDELGEMENTS}

The authors would like to acknowledge CAPES (Higher Education Personnel Improvement Coordination) and the Technical University of Denmark for the support given to this research.

\section{REFERENCES}


[1] EPLCA (2010). European Platform on Life Cycle Assessment, List of tools: Internet site developed by the European Commission. Direction Generale. Joint Research Centre. Institute for Environment and Sustainability. http://lca.jrc.ec.europa.eu/lcainfohub/toolList.vm (accessed in April 2010).

[2] GOEDKOOP, M.; SPRIENSMA. Eco-indicator 99, a damage-oriented method for lifecycle Impact assessment, methodology report. 2000.

[3] Wenzel H., Hauschild MZ and Alting L (1997). Environmental assessment of products. Vol. 1 - Methodology, tools, techniques and case studies, 544 pp. Chapman \& Hall, Kluwer Academic Publishers, Hingham, MA. USA. ISBN 0-412-80800-5.

[4] Potting J and Hauschild MZ (2005). Spatial differentiation in life cycle impact assessment the EDIP2003 methodology. Environmental News n. 80. The Danish Ministry of the Environment, Environmental Protection Agency, Copenhagen.

[5] Guinée JB (ed), Gorrée M, Heijungs R, Huppes G, Kleijn R, de Koning A, van Oers L, Wegener Sleeswijk A, Suh S, Udo de Haes HA, de Bruijn JA, van Duin R, Huijbregts MAJ (2002) Handbook on life cycle assessment: operational guide to the ISO standards. Series: eco-efficiency in industry and science. Kluwer Academic Publishers, Dordrecht (Hardbound, ISBN 1-4020-0228-9; Paperback, ISBN 1-4020-0557-1).

[6] STEEN, B. A Systematic Approach to Environmental Priority Strategies in Product Development Version 2000 - General System Characteristics. Chalmers University of Technology, Centre for Environmental Assessment of Products and material Systems (CPM) Report 1999:4, Gothenburg, 1999.

[7] Jolliet O, Margni M, Charles R, Humbert S, Payet J, Rebitzer G and Rosenbaum R (2003). IMPACT 2002+: A New Life Cycle Impact Assessment Methodology. International Journal of Life Cycle Assessment 8 (6):324-330.

[8] MULLER-WENK, R. The Ecoscarcity Method as a Valuation Instrument within the SETAC Framingwork, in: Udo de Haes/Jensen/Klöpffer/Lindfors (Ed.): Integrating Impact Assessment into LCA, SETAC-Europe, Brussels 1994, p. 115-120.

[9] BARE, J.C.; NORRIS, G.A.; PENNINGTON, D.W.; MCKONE, T. TRACI: The Tool for the Reduction and Assessment of Chemical and Other Environmental Impacts. Journal of Industrial Ecology 6(3), pp. 49-78. 2003.

[10] Goedkoop M, Heijungs R, Huijbregts M, De Schryver A, Struijs J, Van Zelm R (2008). ReCiPe 2008 - A life cycle impact assessment method which comprises harmonized category indicators at the midpoint and the endpoint level. Available at: http://lcia.wik.is.

[11] KEMNA, R.; VAN ELBURG, M.; LI, W.; VAN HOLSTEIN, R. MEEuP - The methodology Report. EC, Brussels. Delft, 2005. 
[12] ITSUBO, N.; SAKAGAMI, M.; WASHIDA, T.; KOKUBU, K.; INABA, A. Weighting Across

\section{Safeguard Subjects for LCIA through the Application of Conjoint Analysis,} International Journal of Life Cycle Assessment, 9 (3) pp. 196-205. 2004.

[13] EC-JRC (2010). European Comission: Joint Research Centre, International Reference Life Cycle Data System (ILCD) Handbook - General guide for Life Cycle Assessment - Detailed guidance.

[14] Hauschild MZ, Goedkoop M, Guinée J, Heijungs R, Huijbregts M, Jolliet O, Margni M, Schryver A, Humbert S. Laurent A, Sala S and Pant R (2012). Identifying best existing practice for characterization modeling in life cycle impact assessment. International Journal of Life Cycle Assessment 18(3):683-697.

[15] Dreyer LC, Niemann AL, Hauschild MZ (2003). Comparison of three different LCIA methods: EDIP97, CML2001 and Eco-indicator 99. International Journal of Life Cycle Assessment 8:191-200.

[16] Pant R, Van Hoof G, Schowanek D, Feijtel TCJ, de Koning A, Hauschild M, Pennington DW, Olsen SI, Rosenbaum R (2004) Comparison between three different LCIA methods for aquatic ecotoxicity and a product environmental risk assessment. International Journal of Life Cycle Assessment 9:295 - 306.

[17] Rosenbaum RK, Huijbregts M, Henderson A, Margni M, McKone TE, van de Meent D, Hauschild MZ, Shaked S, Li DS, Slone TH, Gold LS, Jolliet O (2011). USEtox human exposure and toxicity factors for comparative assessment of toxic emissions in life cycle analysis: sensitivity to key chemical properties. International International Journal of Life Cycle Assessment 16(8):710-727

[18] Caneghem JV, Block C, Vandecasteele C (2010). Assessment of the impact on human health of industrial emissions to air: Does the result depend on the applied method? Journal of Hazardazous Materials 184:788 -797.

[19] Pizzol M, Christensen P, Schmidt JH, Thomsen M (2011a). Impacts of "metals" on human health: a comparison between nine different methodologies for life cycle impact assessment (LCIA). Journal of Cleaner Production 19:646 - 656.

[20] Pizzol M, Christensen P, Schmidt JH, Thomsen M (2011b). Eco-toxicological impact of "metals" on the aquatic and terrestrial ecosystem: a comparison between eight different methodologies for life cycle impact assessment (LCIA). Journal of Cleaner Production 19:687 -698.

[21] Cavalett O, Chagas MF, Seabra JEA, Bonomi A (2012) Comparative LCA of ethanol versus gasoline in Brazil using different LCIA methods. International Journal of Life Cycle Assessment 18:647-658. 
[22] ISO (2006). International Standards Organization, ISO 14044: Environmental management - life cycle assessment requirements and guidelines.

[23] IKP, PE (2002). GaBi 4, Software-System and Databases for Life Cycle Engineering. Copyright, TM. Stuttgart, Echterdingen.

[24] Frischknecht T, Jungbluth N, Althaus HJ, Doka G, Dones R,.; Heck T et al (2005). The ecoinvent database: overview and methodological framework. International Journal of Life Cycle Assessment 10:3-9.

[25] ABNT (2005). Associação Brasileira de Normas Técnicas, NBR 15220 - Desempenho térmico de edificações. Rio de Janeiro, Brazil.

[26] ABNT (2008). Associação Brasileira de Normas Técnicas, NBR 15575 - Edifícios Habitacionais de até cinco pavimentos - Desempenho. Rio de Janeiro, Brazil.

[27] ABNT (2000). Associação Brasileira de Normas Técnicas, NBR 10151 - Acústica Avaliação do ruído em áreas habitadas, visando o conforto da comunidade - Procedimento. Rio de Janeiro, Brazil.

[28] ABNT (1987). Associação Brasileira de Normas Técnicas, NBR 10152 - Níveis de ruído para conforto acústico. Rio de Janeiro, Brazil.

[29] Frischknecht, R.; Jungbluth, N.; Althaus, H.J.; et al (2007). Implementation of life cycle impact assessment methods, Ecoinvent report No.3. Swiss Center for Life Cycle Inventories.

[30] EPE (2011). Empresa de Pesquisa Energética (Brasil). Brazilian Energy Balance 2011 Year 2010 / Empresa de Pesquisa Energética - Rio de Janeiro.

[31] ABAL (2011). Associação Brasileira do Alumínio. Reciclagem no Brasil. Disponivel em: http://www.abal.org.br/reciclagem/brasil.asp.

[32] SEBRAE (2012). Serviço Brasileiro de Apoio às Micro e Pequenas Empresas, Cresce o uso de sucata na produção de aço do país. Disponível em: http://sustentabilidade.sebrae.com.br/portal/site/Sustentabilidade. Acessado em: 10.out.2012. 
Table 1: Indicator metrics for impact categories among the investigated mid-point methodologies.

\begin{tabular}{|c|c|c|c|c|c|}
\hline \multirow{2}{*}{ Impact Categories } & \multicolumn{5}{|c|}{ Indicators } \\
\hline & EDIP 97/2003 & CML 2001 & Impact 2002+ & $\mathrm{ReCiPe}$ & ILCD \\
\hline $\begin{array}{l}\text { Global Warming/Climate } \\
\text { Change }\end{array}$ & kg CO2-eq & kg CO2-eq & $\mathrm{kg} \mathrm{CO} 2-\mathrm{eq}$ & kg CO2-eq & kg CO2-eq \\
\hline Ozone depletion & kg R11-eq & kg R11-eq & kg CFC-11-eq & kg CFC-11-eq & kg CFC-11 eq \\
\hline Acidification & kg SO2-Equiv. & kg SO2-Eq. & kg SO2-Eq. & kg SO2-eq & $\mathrm{AE}$ \\
\hline Eutrophication & kg NO3-Equiv. & kg PO4-Eq. & kg PO4-Eq. & kg P-eq & kg P-eq \\
\hline Photochemical Oxidation & $\mathrm{kg} \mathrm{C} 2 \mathrm{H} 4-\mathrm{Eq}$ & $\mathrm{kg} \mathrm{C} 2 \mathrm{H} 4-\mathrm{Eq}$ & $\mathrm{kg} \mathrm{C} 2 \mathrm{H} 4-\mathrm{Eq}$ & kg NMVOC-eq & kg NMVOC-eq \\
\hline Human toxicity & m3 & kg 1,4-DCB-eq & - & kg 1,4-DCB-eq & cases \\
\hline Ecotoxicity & m3 & kg 1,4-DCB-eq & kg TEG-Eq. & kg 1,4-DCB-eq & - \\
\hline Water Depletion & & & & $\mathrm{m}^{3}$ & $\mathrm{~m}^{3}$ \\
\hline
\end{tabular}


Table 2: Conversion Factor for metrics harmonization.

\begin{tabular}{|c|c|c|c|c|c|}
\hline \multirow{2}{*}{$\begin{array}{l}\text { Impact Categories and } \\
\text { harmonization unit }\end{array}$} & \multicolumn{5}{|c|}{ Conversion factors } \\
\hline & EDIP 97/2003 & CML 2001 & Impact 2002+ & $\mathrm{ReCiPe}$ & ILCD \\
\hline Global Warming [kg CO2-Equiv.] & 1,0 & 1,0 & 1,0 & 1,0 & 1,0 \\
\hline Ozone depletion [kg CFC-11 eq] & 1,0 & 1,0 & 1,0 & 1,0 & 1,0 \\
\hline Acidification [kg SO2-Equiv] & 1,0 & 1,0 & 1,0 & 1,0 & - \\
\hline Eutrophication [kg NO3-Equiv.] & 1,0 & 10,44 & 10,44 & 32 & 4,43 \\
\hline $\begin{array}{l}\text { Photochemical Oxidation [kg } \\
\text { NMVOC-eq] }\end{array}$ & 1,7 & 1,7 & 1,7 & 1,0 & 1,0 \\
\hline Human toxicity [kg 1,4-DCB-eq] & $\begin{array}{c}\text { 1,40E-5 (air) } \\
\text { 1,12E-2 (water) } \\
1,43 \text { (soil) }\end{array}$ & 1,0 & - & 1,0 & - \\
\hline Ecotoxicity [kg 1,4-DCB-eq] & $\begin{array}{c}\text { 1,40E-5 (air) } \\
\text { 1,12E-2 (water) } \\
1,43 \text { (soil) }\end{array}$ & 1,0 & $1,62 \mathrm{E}-3$ & 1,0 & - \\
\hline Water Depletion [m³] & - & - & - & $\overline{m^{3}}$ & $\overline{m^{3}}$ \\
\hline
\end{tabular}


Table 3: Sensitivity Analysis to different LCIA methods.

\begin{tabular}{|c|c|c|c|c|c|}
\hline \multicolumn{2}{|c|}{ Impact category per LCIA method (Harmonized units) } & $\begin{array}{l}\text { Masonry of } \\
\text { Clay } \\
\text { Blocks }\end{array}$ & $\begin{array}{c}\text { Masonry of } \\
\text { Concrete } \\
\text { Blocks }\end{array}$ & $\begin{array}{c}\text { Lightweight } \\
\text { Concrete } \\
\text { Wall }\end{array}$ & $\begin{array}{c}\text { Steel } \\
\text { Framing } \\
\text { system with } \\
\text { internal and } \\
\text { external fiber } \\
\text { cement } \\
\text { panels }\end{array}$ \\
\hline \multirow{5}{*}{$\begin{array}{c}\text { Global } \\
\text { warming [kg } \\
\text { CO2-Eq.] }\end{array}$} & EDIP 1997, Global warming & 0,625 & 0,234 & 0,625 & 0,659 \\
\hline & CML2001, Global Warming Potential & 0,620 & 0,233 & 0,621 & 0,652 \\
\hline & I02+v2.1 - Global warming 500yr - Midpoint & 0,602 & 0,229 & 0,622 & 0,636 \\
\hline & ReCiPe Midpoint $(\mathrm{H})$ - Climate change & 0,631 & 0,240 & 0,639 & 1,000 \\
\hline & ILCD Midpoint - Climate change & 0,631 & 0,240 & 0,639 & 1,000 \\
\hline \multirow{5}{*}{$\begin{array}{c}\text { Ozone } \\
\text { Depletion [kg } \\
\text { CFC-11-Eq.] }\end{array}$} & EDIP 2003, Stratospheric ozone depletion & 0,382 & 0,130 & 0,411 & 0,307 \\
\hline & CML2001, Ozone Layer Depletion Potential & 0,517 & 0,132 & 0,433 & 0,360 \\
\hline & I02+v2.1 - Ozone layer depletion - Midpoint & 0,580 & 0,133 & 0,447 & 0,386 \\
\hline & ReCiPe Midpoint $(\mathrm{H})$ - Ozone depletion & 0,580 & 0,133 & 0,454 & 1,000 \\
\hline & ILCD Midpoint - Ozone depletion & 0,580 & 0,133 & 0,454 & 1,000 \\
\hline \multirow{5}{*}{$\begin{array}{c}\text { Photochemical } \\
\text { Oxidation (kg } \\
\text { NMVOC-eq] }\end{array}$} & EDIP 1997, Photochemical oxidant potential (high NOx) & 0,187 & 0,078 & 0,209 & 0,298 \\
\hline & CML2001, Photochem. Ozone Creation Potential & 0,207 & 0,088 & 0,298 & 0,312 \\
\hline & I02+ v2.1 - Photochemical oxidation & 0,187 & 0,078 & 0,163 & 0,241 \\
\hline & ReCiPe - Photochemical oxidant formation & 1,000 & 0,460 & 0,948 & 0,890 \\
\hline & ILCD - Photochemical oxidant formation & 1,000 & 0,460 & 0,948 & 0,890 \\
\hline \multirow{4}{*}{$\begin{array}{l}\text { Acidification } \\
\text { [kg SO2-eq.] }\end{array}$} & EDIP 1997, Acidification potential & 0,562 & 0,256 & 1,079 & 0,716 \\
\hline & CML2001, Acidification Potential & 0,560 & 0,256 & 1,076 & 0,713 \\
\hline & $102+v 2.1$ - Terrestrial acidification/nutrification & 3,353 & 1,578 & 3,481 & 3,185 \\
\hline & ReCiPe - Terrestrial acidification & 0,476 & 0,219 & 1,000 & 0,647 \\
\hline \multirow{5}{*}{$\begin{array}{l}\text { Eutrophication } \\
\text { [kg NO3-eq.] }\end{array}$} & EDIP 1997, Nutrient Enrichment Potential & 1,635 & 0,785 & 1,963 & 2,360 \\
\hline & CML2001, Eutrophication Potential & 6,204 & 2,958 & 8,328 & 10,236 \\
\hline & I02+v2.1 - Aquatic eutrophication & 0,125 & 0,074 & 0,625 & 1,004 \\
\hline & ReCiPe - Freshwater eutrophication & 0,125 & 0,075 & 0,631 & 1,000 \\
\hline & ILCD - Marine eutrophication & 6,068 & 2,819 & 5,320 & 5,350 \\
\hline \multirow{3}{*}{$\begin{array}{c}\text { Terrestrial } \\
\text { Ecotoxicity [kg } \\
\text { 1,4-DCB-Eq.] }\end{array}$} & EDIP 1997, Ecotoxicity soil chronic & 443,423 & 435,845 & 519,709 & 2897,210 \\
\hline & CML2001, Terrestric Ecotoxicity Potential & 9,497 & 6,592 & 31,380 & 76,860 \\
\hline & ReCiPe Midpoint $(H)$ - Terrestrial ecotoxicity & 0,150 & 0,050 & 0,233 & 1,000 \\
\hline \multirow{3}{*}{$\begin{array}{c}\text { Aquatic } \\
\text { Ecotoxicity [kg } \\
\text { 1,4-DCB-Eq.] }\end{array}$} & EDIP 1997, Ecotoxicity water chronic & 82,749 & 18,937 & 7665,550 & 714,289 \\
\hline & CML2001, Freshwater Aquatic Ecotoxicity Pot. & 6,218 & 3,410 & 42,273 & 53,174 \\
\hline & ReCiPe Midpoint $(\mathrm{H})$ - Freshwater ecotoxicity & 0,114 & 0,083 & 0,546 & 1,000 \\
\hline \multirow{5}{*}{$\begin{array}{l}\text { Human } \\
\text { Toxicity [kg } \\
\text { 1,4-DCB] }\end{array}$} & EDIP 1997, Human toxicity air & 40,799 & 26,451 & 54,287 & 126,608 \\
\hline & EDIP 1997, Human toxicity soil & 2,950 & 0,899 & 2,348 & 3,553 \\
\hline & EDIP 1997, Human toxicity water & 0,629 & 0,489 & 1,713 & 5,027 \\
\hline & CML2001, Human Toxicity Potential & 1,367 & 0,727 & 3,604 & 7,876 \\
\hline & ReCiPe Midpoint $(\mathrm{H})$ - Human toxicity & 0,146 & 0,064 & 0,583 & 1,000 \\
\hline \multirow{2}{*}{$\begin{array}{c}\text { Water } \\
\text { Depletion }\left[\mathrm{m}^{3}\right]\end{array}$} & ReCiPe Midpoint $(\mathrm{H})$ - Water depletion & 0,120 & 0,091 & 1,000 & 0,711 \\
\hline & ILCD Midpoint - Water depletion & 0,016 & 0,008 & 0,043 & 0,095 \\
\hline \multirow{4}{*}{\multicolumn{2}{|c|}{ Legend }} & & \multicolumn{3}{|c|}{ Lowest impact alternative } \\
\hline & & & \multicolumn{3}{|c|}{ Second Lower impact alternative } \\
\hline & & & \multicolumn{3}{|c|}{ Third Lower impact alternative } \\
\hline & & & \multicolumn{3}{|c|}{ Highest impact alternative } \\
\hline
\end{tabular}




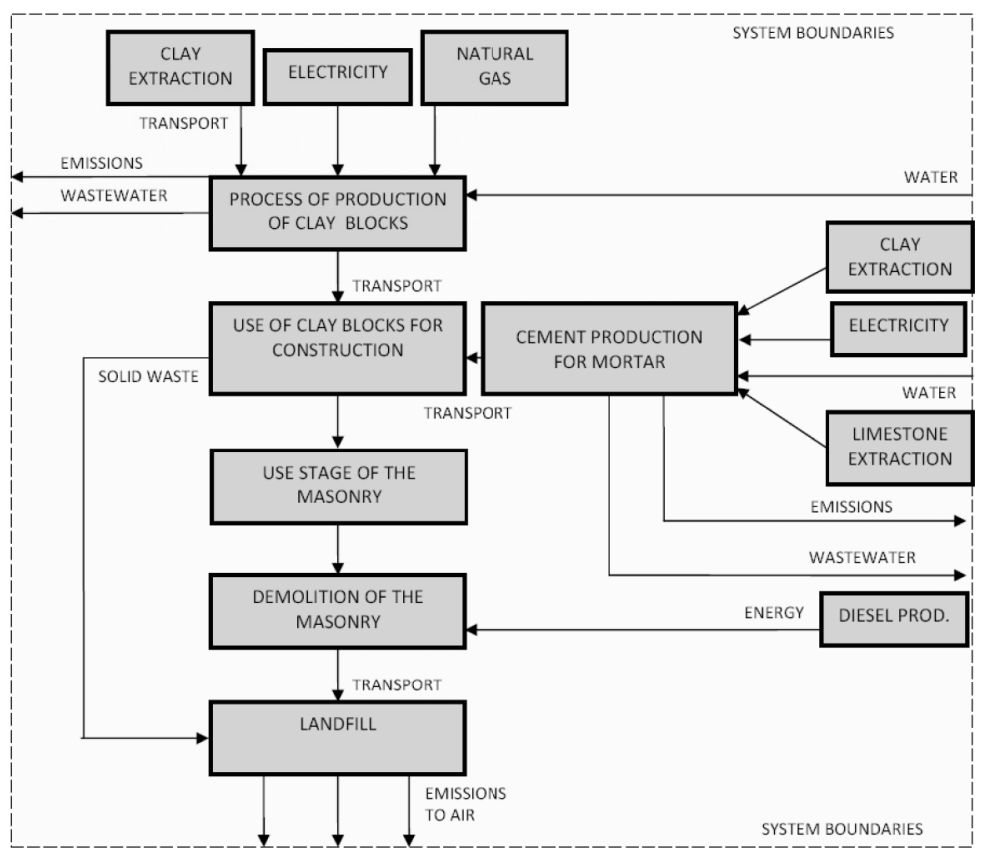

Figure 1: System Boundaries of Clay Blocks Masonry and system boundaries.

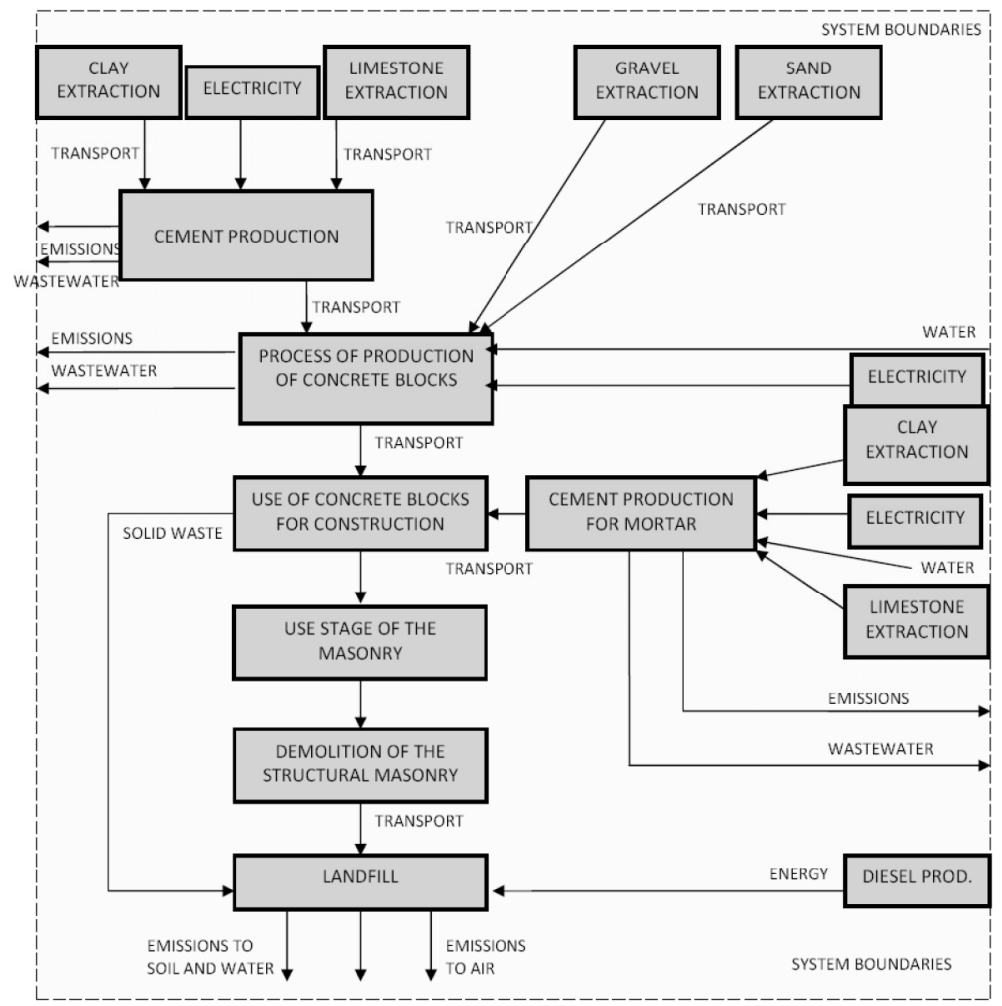

Figure 2: System Boundaries of Concrete Blocks Masonry and system boundaries. 


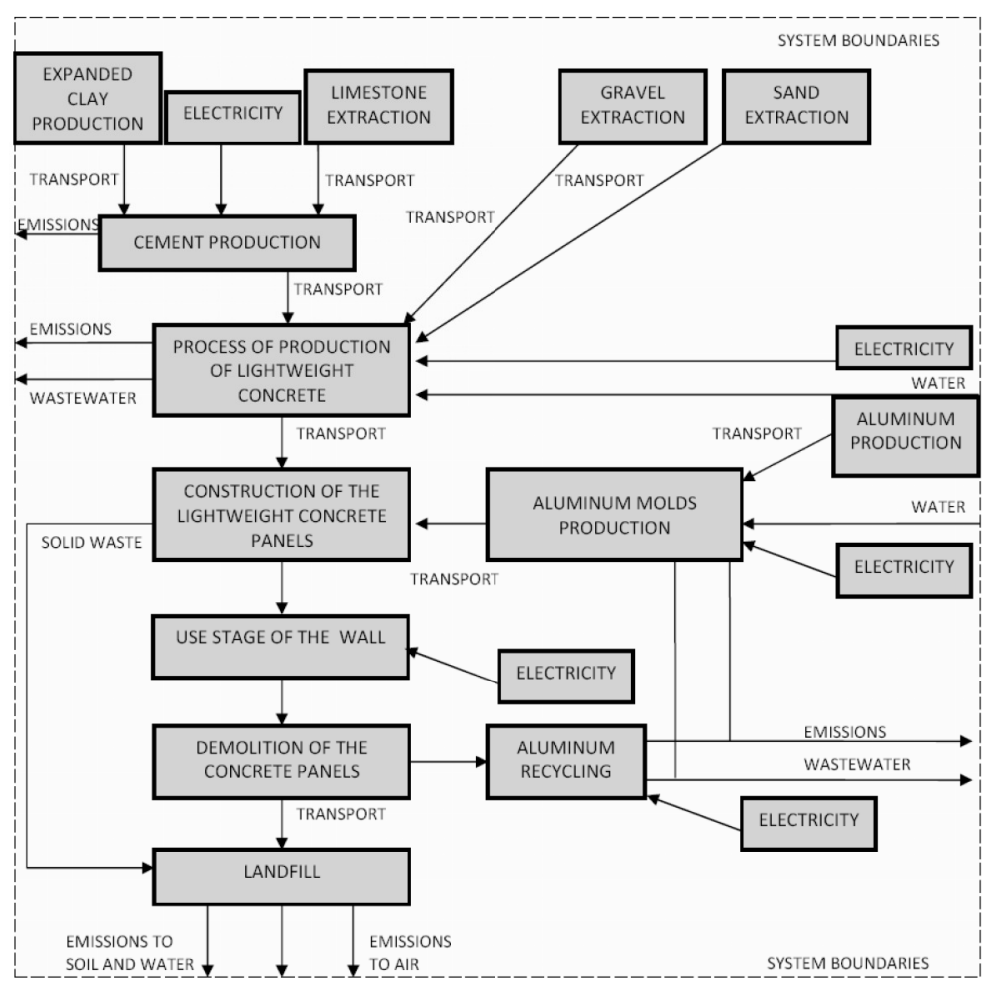

Figure 3: Product System of Lightweight concrete walls

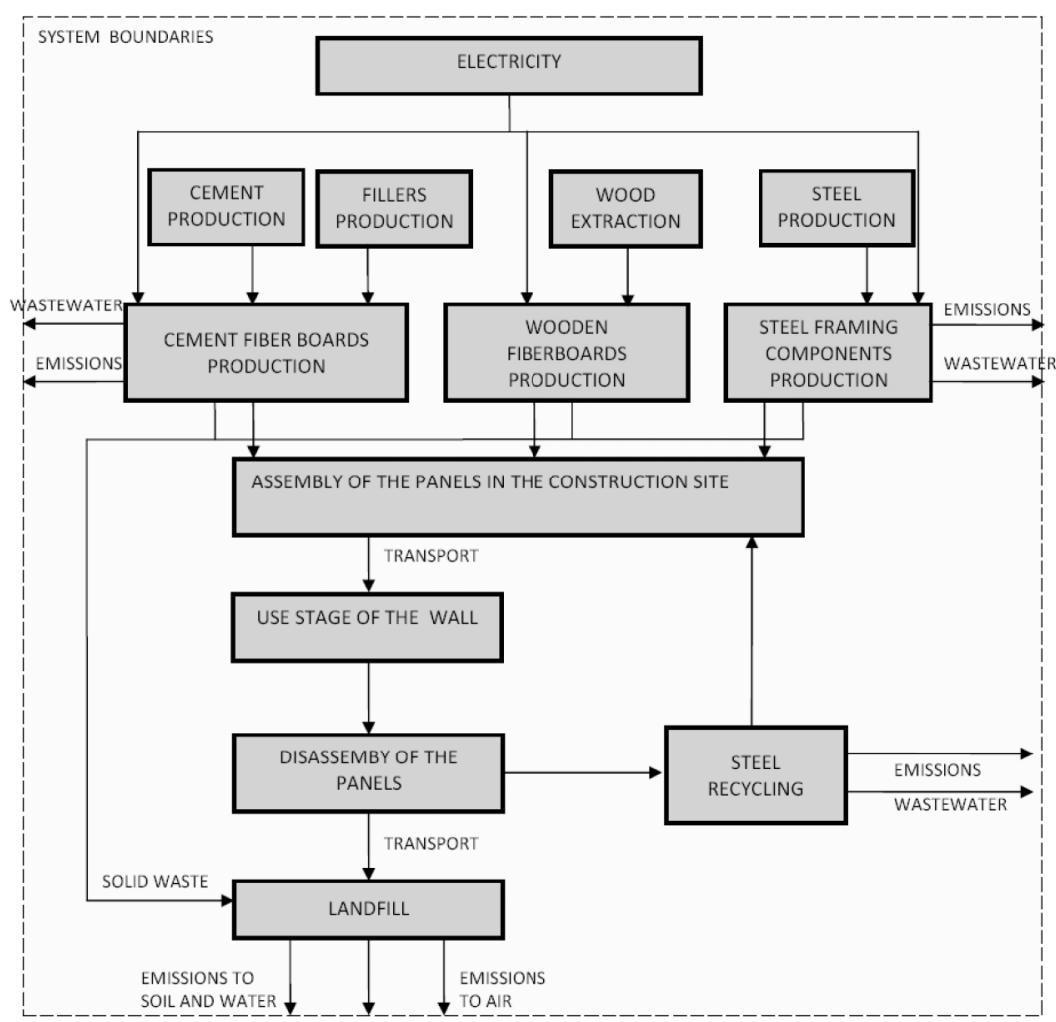

Figure 4: Product System of Steel framing walls system with internal and external wood-filled fibercement boards. 


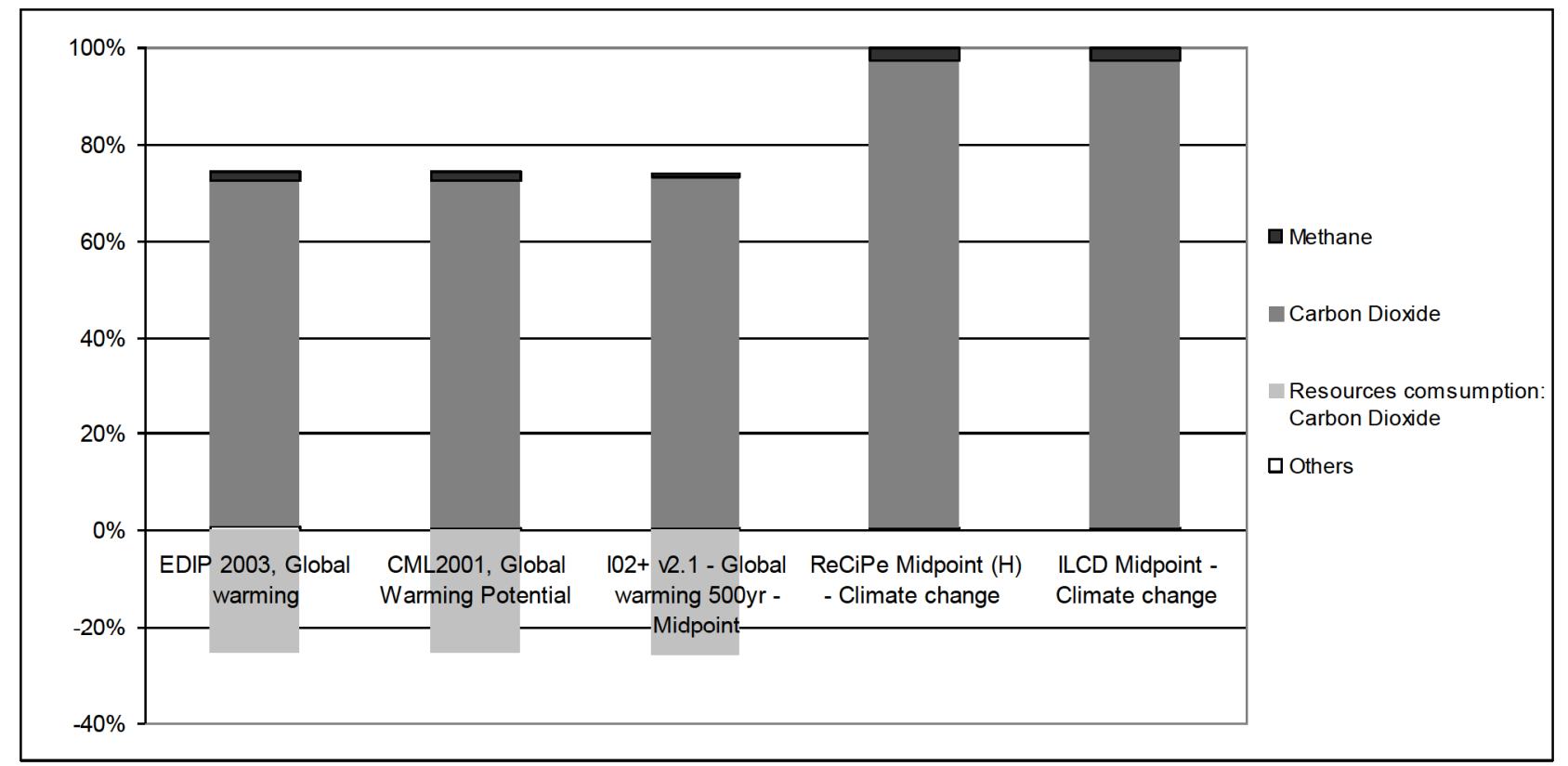

Figure 5: Contribution Analysis in the Global Warming impact Category for the Masonry of Clay Blocks wall system.

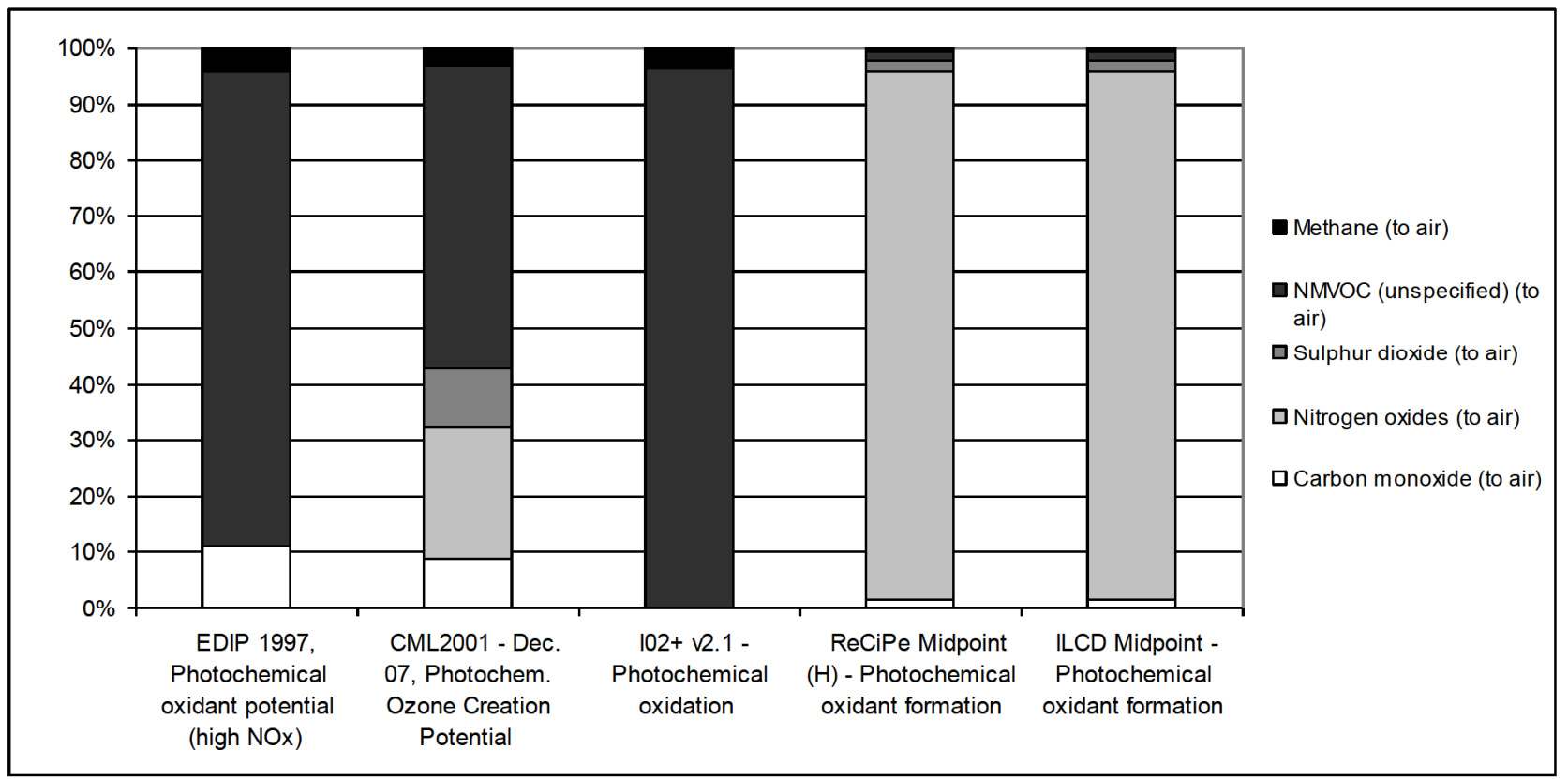

Figure 6: Contribution Analysis in the Photochemical Oxidation impact Category for the Masonry of Clay Blocks. 


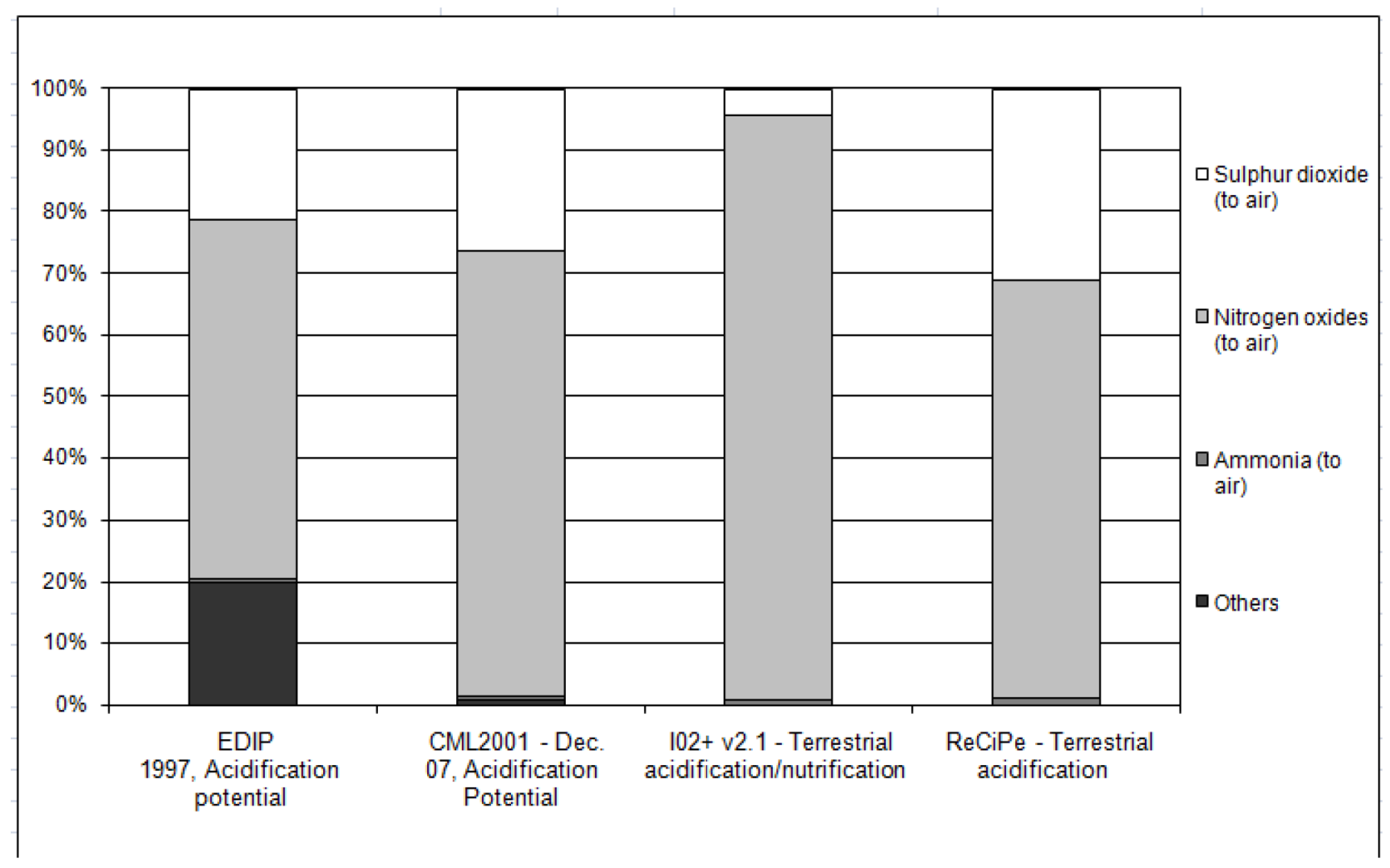

Figure 7: Contribution Analysis in the Acidification impact category for the Masonry of Clay Blocks.

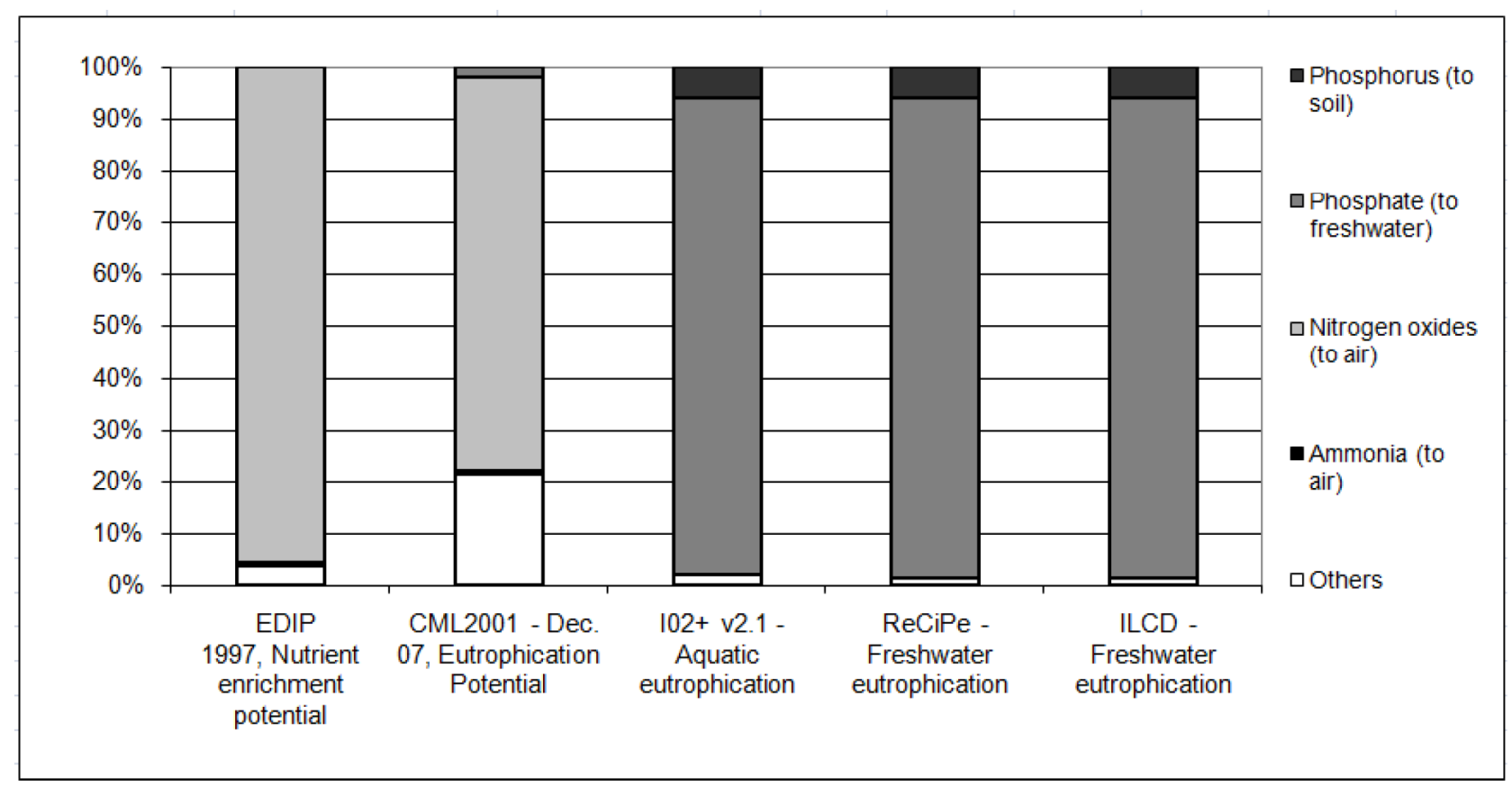

Figure 8: Contribution Analysis in the Eutrophication impact category for the Masonry of Clay Blocks. 


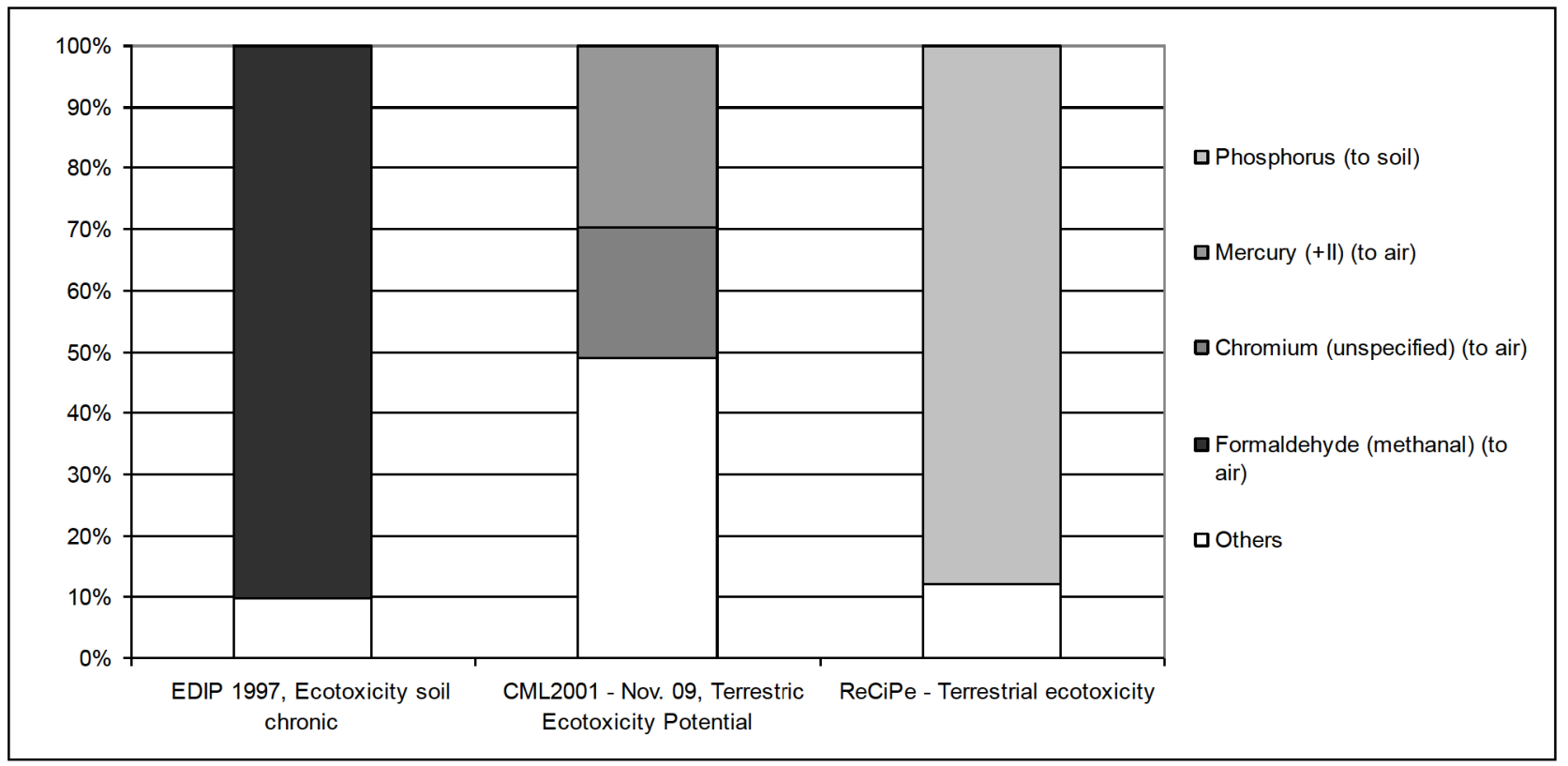

Figure 9: Contribution Analysis in the Terrestrial Ecotoxicity impact category for the Masonry of Clay Blocks.

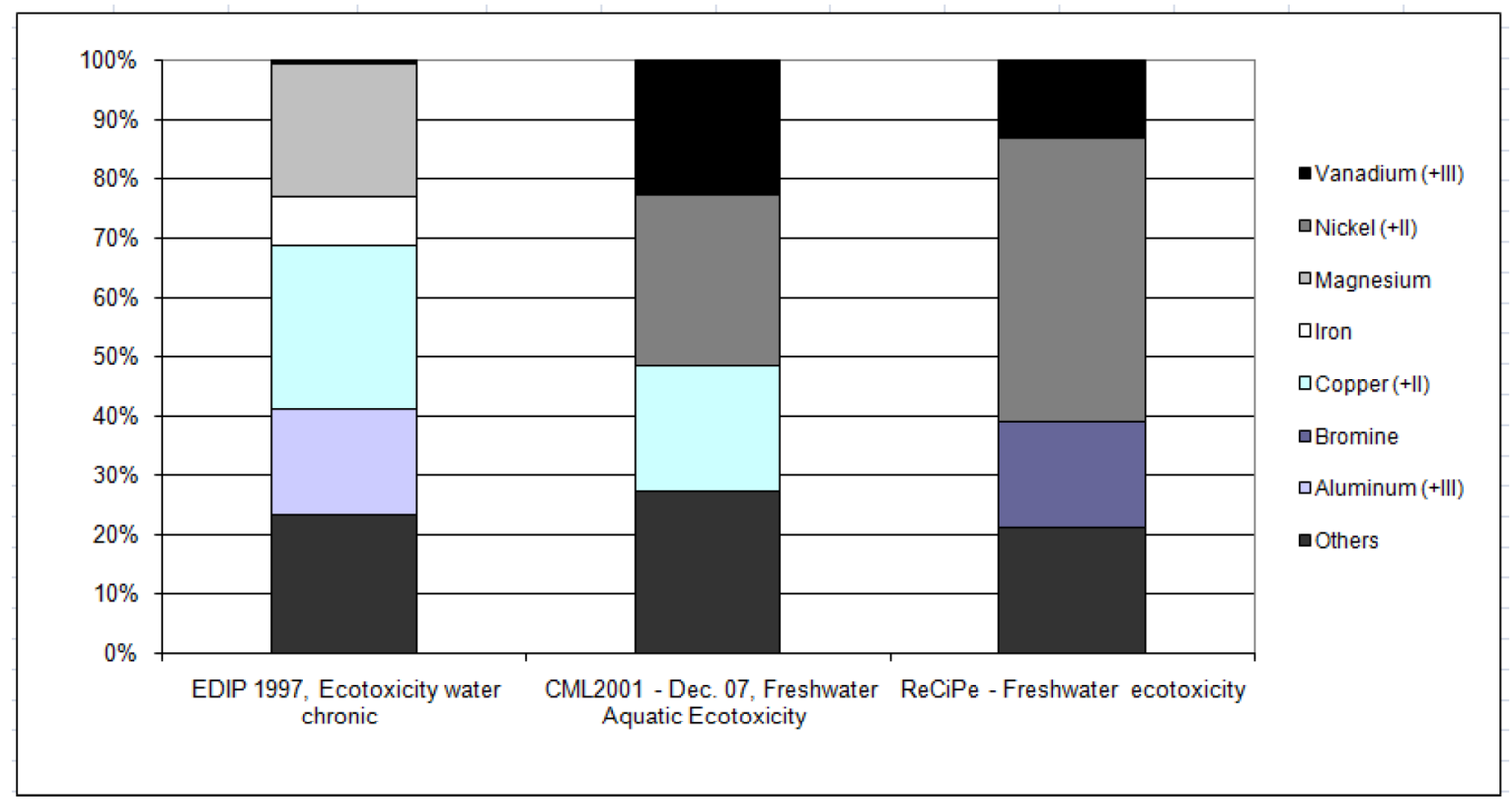

Figure 10: Contribution Analysis in the Aquatic Ecotoxicity impact category for the Masonry of Clay Blocks. 


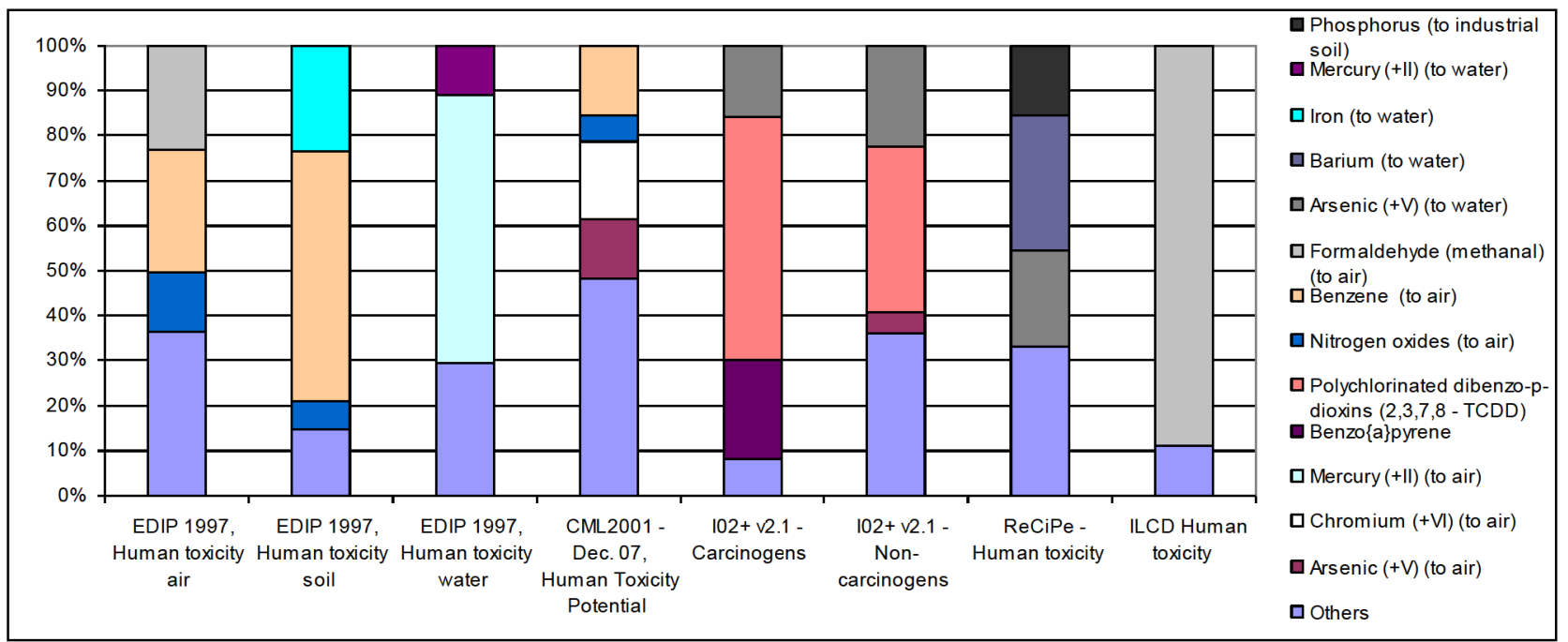

Figure 11: Contribution Analysis in the Human Toxicity impact category for the Masonry of Clay Blocks. 
Click here to download e-component: BUENOC_APPENDIX.pdf 